\title{
Influence of the genetic makeup of common carp on the expression of iron-related genes during Trypanoplasma borreli infection
}

\author{
Teresa Kamińska-Gibas, Ilgiz Irnazarow, Joanna Szczygieł, Patrycja Jurecka \\ Polish Academy of Sciences, \\ Institute of Ichthyobiology and Aquaculture in Gołysz, Zaborze, 43-520 Chybie, Poland \\ patrycja.jurecka@golysz.pan.pl
}

Received: May 16, 2018

Accepted: September 18, 2018

\begin{abstract}
Introduction: Genes related to iron metabolism play an important role in inflammatory response. The objective of this study was to investigate the role of ferritin, transferrin receptors 1a and $1 \mathrm{~b}$, and transferrin genes in the response to blood parasite infection in common carp (Cyprinuscarpio L.). Material and Methods: Two genetically distinct carp groups were used: R3 carp, which are established as being sensitive to parasitic infection, and SA carp (Cyprinus carpio haematopterus) of wild origin. An established challenge model with Trypanoplasma borreli was applied. Challenged carp were sampled to determine their expression levels of transferrin receptors $1 \mathrm{a}$ and $1 \mathrm{~b}$, ferritin, and transferrin mRNA. Mortality and serum iron concentration were also measured. Results: The study revealed contrasting differences in the expression profiles of all key iron regulatory genes except the transferrin gene. In the case of other parameters, significant differences were also observed. Conclusion: Our results demonstrate that the level of parasitic infection depends on the blood iron status. This parameter was related to the origin of the fish.
\end{abstract}

Keywords: carp, gene expression, transferrin, Trypanoplasma borreli.

\section{Introduction}

Iron is essential to the growth and survival of most living organisms. It serves as a cofactor in many metabolic processes such as DNA replication, transcription, electron transport in mitochondria, and nucleotide synthesis. Moreover, iron plays a crucial role in immunity, as it is an essential nutrient for pathogenic microorganisms (17). The liver is a key organ in iron metabolism, as it is the primary site of iron storage. Most proteins involved in iron homeostasis are synthesised in this organ.

During the last decade, the roles of ferritin (iron storage protein), transferrin (iron transporter protein), and transferrin receptor in the maintenance of iron homeostasis have been largely delineated (10). It has been shown that ferritin expression in cells increases when iron concentration is high and decreases when the concentration lowers. In the first case, iron is deposited in the liver, and in the second case, iron is released into the bloodstream. In contrast, the synthesis of transferrin receptor mRNA is increased at low iron concentration, resulting in increased transferrin receptor synthesis and a corresponding increased iron uptake by the cell, and receptor synthesis is repressed at high iron concentration (1). It was demonstrated that the transferrin mRNA level is also higher in iron deficiency conditions, which correlates with an increase in iron absorption.

The expression of these proteins is also altered during an attack of pathogens, indicating their participation in both iron metabolism and the inflammatory response. Mammalian ferritin and transferrin are considered to be acute phase proteins, and their concentration changes in the case of trauma, injury or infection. Ferritin concentration has been shown to increase by up to three times its initial concentration, which justifies its classification as an acute phase positive protein (24). This stands in contrast to transferrin whose concentration may either decrease (9) or increase (21).

Similarly to mammals, many fish show upregulation of transferrin expression following infection or treatment with stimulants. Researchers 
have reported this phenomenon in rainbow trout (Oncorhynchus mykiss, Walbaum) (2) and channel catfish (Ictalurus punctatus, Rafinesque) (20, 13). Transferrin downregulation is described for sea bass (Dicentrarchus labrax L.) (19), roughskin sculpin (Trachidermus fasciatus, Heckel) (14), and ayu (Plecoglossus altivelis, Temminck \& Schlegel) (16). Ferritin expression, by contrast, is usually upregulated as in Atlantic cod (Gadus morhua L.) (7), rock bream (Oplegnathusfasciatus, Temminck \& Schlegel) (6), Asian seabass (Lates calcarifer, Bloch) (18), and channel catfish (20). Although transferrin receptor is not classified as an acute phase protein, its expression is altered during infection due to changes in the amount of iron in the body $(1,29)$.

Common carp (Cyprinus carpio L.) is a widespread breeding species of high economic importance. Infectious diseases in carp aquaculture cause serious problem for farmers and lead to significant financial losses. In common carp, several genes involved in iron metabolism have been identified and changes in their activity during infection demonstrated. Jurecka et al. (11) obtained coding DNA sequences of different transferrin alleles and showed differential expression in healthy fish and fish infected with Trypanoplasma borreli (unpublished data). However, despite these studies, the available information about the interactions between pathogen, host, and iron metabolism in carp is limited. Likewise, the number of iron-related genes, and their mode of action have not been investigated.

The aim of the study was to analyse two commercially exploited carp groups of different genetic backgrounds that demonstrate different susceptibility to infections. We report an experimental infection of common carp with the blood parasite Trypanoplasma borreli which causes a slow infection development rate. During our experiments, we determined individual levels of parasitaemia. Serum and liver samples were collected, and the expression levels of key genes involved in iron metabolism were determined. These were transferrin receptors, transferrin, and ferritin. The influence of iron status and potential role of ironrelated genes during the infection in those carp groups are discussed.

\section{Material and Methods}

Two carp strains, R3 and SA, known for their differences in disease resistance, were selected to be challenged with Trypanoplasma borreli. After fish were infected, gene activity was analysed, and levels of serum iron were monitored.

Fish. The authors artificially reproduced individual mature carp (at the age of five years) from the Polish R3 strain and SA wild carp (of the Amur River, bordering Russia and China), which form part of the live gene bank of the Institute of Ichthyobiology and Aquaculture in Gołysz (5). The fry were grown in a recirculation aquarium system according to standard procedures. Water parameters (temperature $22^{\circ} \mathrm{C}$, ammonium $0.1-0.2 \mathrm{mg} / \mathrm{L}$, oxygen saturation 6.0 $7.0 \mathrm{mg} / \mathrm{L}, \mathrm{pH}$ 7) were monitored daily to ensure consistency. At the age of 12 months and average weight of $100 \pm 25 \mathrm{~g}$, the fish were used for experiments.

Trypanoplasma borreli infection. Trypanoplasma borreli, initially cloned and characterised according to the procedure described by Steinhagen et al. (22), were maintained by syringe passage through susceptible carp (R3xR8). Carp were anaesthetised with $0.2 \%$ propiscin (12) prior to intraperitoneal infection with $2.6 \times 10^{5}$ parasites per fish. In total, 130 R3 and 130 SA individuals were infected. Among them, 20 individuals in each carp strain were tagged with passive integrated transponder tags. Marked fish were used to trace the level of parasitaemia weekly. At each sampling point, 10 fish from each carp strain were euthanised with $0.2 \%$ propiscin in order to collect liver and blood samples. Approximately $5 \mu \mathrm{L}$ of blood was collected into heparinised Eppendorf tubes and then diluted 1:40 with PBS. The number of parasites was counted using a Bürker counting chamber. The remaining blood was collected as described previously. Liver and serum samples were stored in RNAlater at $-80^{\circ} \mathrm{C}$. Each of these steps was repeated at weekly intervals, starting from the second and continuing until the sixth week post infection (p.i.). During the course of $T$. borreli infection, mortality in the challenged groups was recorded three times per day. Water parameters like temperature, oxygen saturation, ammonium nitrogen, and $\mathrm{pH}$ were monitored on a daily basis.

RNA isolation and cDNA synthesis. Total RNA was isolated from the liver of infected carp, using the SV Total RNA Isolation System (no. TM048, Promega, USA), according to the standard protocol. To obtain cDNA, a GoScript Reverse Transcriptase Kit (no. G2101, Promega, USA) was used. The amplification scheme was $5 \mathrm{~min}$ of annealing at $25^{\circ} \mathrm{C}$, up to one hour of extension at $42^{\circ} \mathrm{C}$, and $15 \mathrm{~min}$ of reverse transcriptase inactivation at $70^{\circ} \mathrm{C}$.

Quantitative real-time PCR. Real-time PCR was conducted, using Maxima SYBR Green qPCR Master Mix2x (no. K0252, Thermo Scientific, USA) and fluorescent double-stranded DNA (dsDNA)-binding dye SYBR Green. All procedures were carried out in accordance with the kits' protocols. A volume of $5 \mu \mathrm{L}$ of each cDNA sample was added to a reaction mix, containing $12.5 \mu \mathrm{L}$ of GoTaq qPCR Master Mix 2x, $5.5 \mu \mathrm{L}$ of nuclease-free $\mathrm{H}_{2} \mathrm{O}$, and $1 \mu \mathrm{L}$ (concentration $10 \mu \mathrm{M}$ ) of each primer, making a total volume of $25 \mu \mathrm{L}$ per reaction. Each sample was prepared in duplicate. A non-template control was included for each set of primers. The following cycling profile was applied: $50^{\circ} \mathrm{C}$ for $2 \mathrm{~min}, 95^{\circ} \mathrm{C}$ for $10 \mathrm{~min}, 40$ cycles of $95^{\circ} \mathrm{C}$ for $15 \mathrm{~s}, 60^{\circ} \mathrm{C}$ for $1 \mathrm{~min}$, and $72^{\circ} \mathrm{C}$ for $30 \mathrm{~s}$, with the final holding stage at $60^{\circ} \mathrm{C}$ for $1 \mathrm{~min}$. As a control, the $40 \mathrm{~S}$ 
ribosomal protein $\mathrm{S} 11$ gene was used. The comparative $2^{-\Delta \Delta \mathrm{Ct}}$ method based on $\mathrm{C}_{\mathrm{T}}$ values (15) for transferrin (Tf), ferritin (Fer), and transferrin receptors 1a and 1b (TfR1a and TfR1b) was used to determine the expression levels. The primers used in qRT-PCR analysis are shown in Table 1.

Table 1. qRT-PCR primers used in this study

\begin{tabular}{lll}
\hline Gene & Primer & Sequence (5'-3') \\
\hline TfR1a & F & TCATACCCAGTTTCCCCCAG \\
\hline & $\mathrm{R}$ & GGTATCCCGAAGCATCCCAT \\
\hline TfR1b & $\mathrm{F}$ & GAGCTGGAAAAATCAGCATGG \\
\hline & $\mathrm{R}$ & GGAATCCTGGGGTGTAAGGA \\
\hline $\mathrm{Tf}$ & $\mathrm{F}$ & CCCTCAGCCAGTGCTCAAAA \\
\hline & $\mathrm{R}$ & ATAGCATCTGCATCACCAGTC \\
\hline Fer & $\mathrm{F}$ & TGGAGCTGTATGCATCCTACG \\
\hline & $\mathrm{R}$ & CCCTCCCCTCTGGTTCTGA \\
\hline $40 \mathrm{~S}$ & $\mathrm{~F}$ & CCGTGGGTGACATCGTTACA \\
\hline & $\mathrm{R}$ & TCAGGACATTGAACCTCACTGTCT
\end{tabular}

Iron concentration. To measure serum iron concentration, a Ferentest kit (no. 61076, Biomérieux, France) was used according to the manufacturer's instructions, with modifications. Briefly, $25 \mu \mathrm{L}$ of serum sample was added to $125 \mu \mathrm{L}$ of working solution (guanidine hydrochloride $5.76 \mathrm{mmol} / \mathrm{L}$ with thiourea $39.4 \mathrm{mmol} / \mathrm{L}$ and ascorbic acid) and mixed. Simultaneously with the measured samples, reagent blank and standard were prepared. The mixture was left for $5 \mathrm{~min}$ at room temperature, and then absorbance was measured. Next, a colour reagent containing Ferene $\mathrm{S}$ in an acetate buffer was added and mixed, using a shaker. After $10 \mathrm{~min}$ at room temperature, the second absorbance was measured. The intensity of the coloration measured was proportional to the quantity of iron present in the sample. All absorbance was measured at a wavelength of $593 \mathrm{~nm}$, using a SpectraMax i3 multimode plate reader (Molecular Devices, USA). Serum iron was calculated using the equation: sample concentration $=((\mathrm{OD} 2-\mathrm{OD} 1 \mathrm{sample}) /$ $(\mathrm{OD} 2-\mathrm{OD} 1$ standard $)) \times \mathrm{n}$, where $\mathrm{n}=$ concentration of standard.

Statistical analysis. The non-parametric KruskalWallis test was applied to test differences in gene expression between infected and non-infected fish (control group, 5 fish per line). The same test was used for the differences between individuals of the two carp strains at each time point. Differences at $\mathrm{P} \leq 0.05$ were considered statistically significant. All analyses were performed, using MedCalc software (MedCalc 14.12.0, Belgium).

\section{Results}

Control groups are not shown in the Figs 1 and 2 because neither mortality nor parasites in the blood were recorded. In Figs 3 and 4A-D, control groups correspond to the $0 \mathrm{~W}$ time point.

Mortality. The first mortalities in the R3 strain were noted from week 2 p.i., with the last ones detected in week 3 p.i. (Fig. 1). In the SA line, the death of a single individual in week 3 p.i. was recorded. By the end of experiment, i.e. after six weeks of observations, the overall survival rate was $75.4 \%$ for R3 and $99.2 \%$ for SA carp. In the control group, no mortality was noticed (not shown).

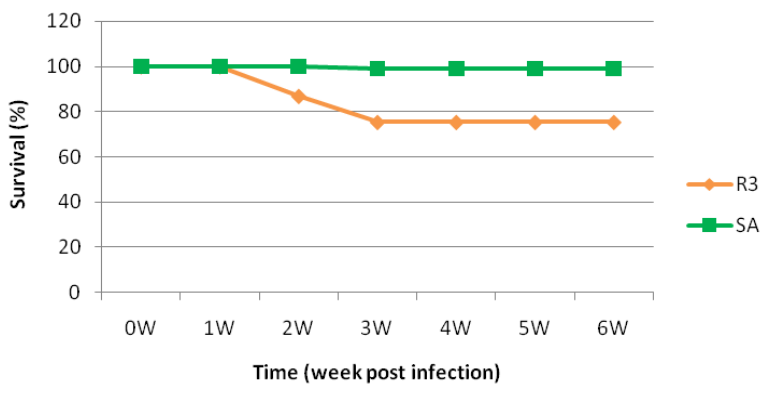

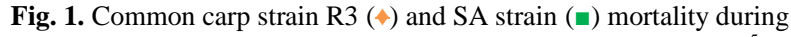
Trypanoplasma borreli infection. Carp were infected with $2.6 \times 10^{5}$ of T. borreli

Parasitaemia. Individuals from the R3 strain developed significantly higher parasitaemia than the SA carp. In addition, the R3 individuals showed two peaks of parasitaemia at weeks 2 and 5 p.i., while in $\mathrm{SA}$, an increased parasite number occurred in week 2 p.i. only (Fig. 2).

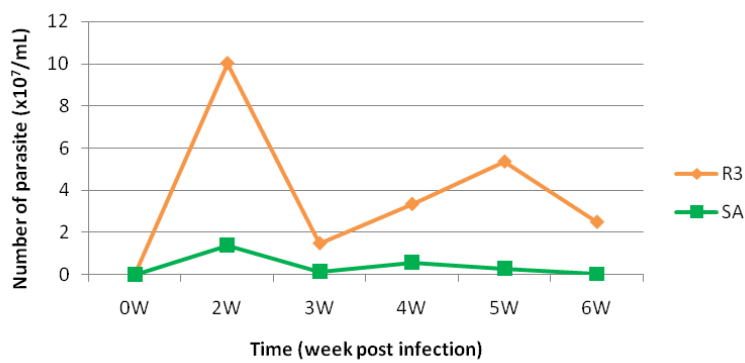

Fig. 2. Parasitaemia of common carp strain R3 (*) and SA strain ( $\bullet$ ). Carp were infected with $2.6 \times 10^{5}$ of $T$. borreli. The values are means for blood samples from groups of $n=20$ fish. Differences between carp strains are significant $(\mathrm{P} \leq 0.05)$ for each time point except $0 \mathrm{~W}$

Serum iron concentration. SA carp had an initial mean serum iron concentration almost three times higher than R3 fish (Fig.3). The developing T. borreli infection induced a continuous decrease in serum iron value which was lowest at week 4 p.i. in R3 carp. SA carp showed a similar tendency, but it was not statistically significant. By weeks 5 and 6 p.i., a restoration of the serum iron pool was observed. There was no correlation between individual parasite 
counts and serum iron concentration in R3 and SA carp.

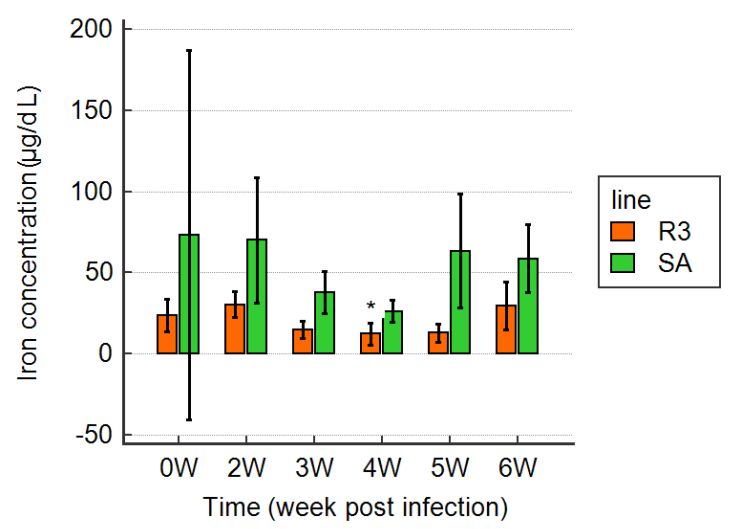

Fig. 3. Serum iron concentration $\left(\mu \mathrm{g} \mathrm{dL}^{-1}\right)$ in strains R3 ( $\left.₫\right)$ and SA ( $\bullet$ ) during $T$. borreli infection. The values are means $\pm \mathrm{SD}$ for blood samples from groups of $n=10$ fish. Differences between the control group (not shown) and strains R3 and SA were considered significant for $\mathrm{P} \leq 0.05$ and marked with an asterisk

Transferrin receptor $1 \mathrm{a}$ and $1 \mathrm{~b}$, transferrin, and ferritin expression during parasite infection. The same set of genes comprising TfR1a, TfR1b, transferrin, and ferritin were measured for their expression activity using a quantitative real-time PCR at weeks 2 and 3 post $T$. borreli infection.

TfR1a (Fig. 4A) activity demonstrated opposite trends in the two challenged carp groups. Moderate and continuous upregulation in R3 carp was observed, while SA fish showed substantial downregulation. Differences between those carp lines were significant. The expression of TfR1b (Fig. 4B) increased significantly at weeks 2 and 3 p.i. in SA carp and remained at the level of the control group in R3 carp.

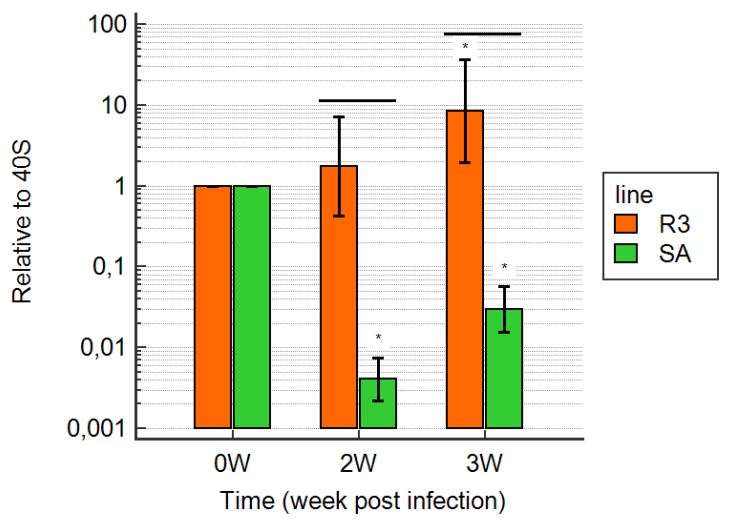

Fig. 4A. Transferrin receptor 1a expression in strain R3 ( $\square$ ) and SA (๘) during Trypanoplasma borreli infection. Values after log transformation are expressed as a fold change $\pm \mathrm{SD}$ relative to $40 \mathrm{~S}$ $(\mathrm{n}=5)$. Differences between the control group (not shown) and strains R3 and SA were considered significant for $\mathrm{P} \leq 0.05$ and marked with an asterisk. Differences between the strains were considered significant for $\mathrm{P} \leq 0.05$ in each time point and marked by a line

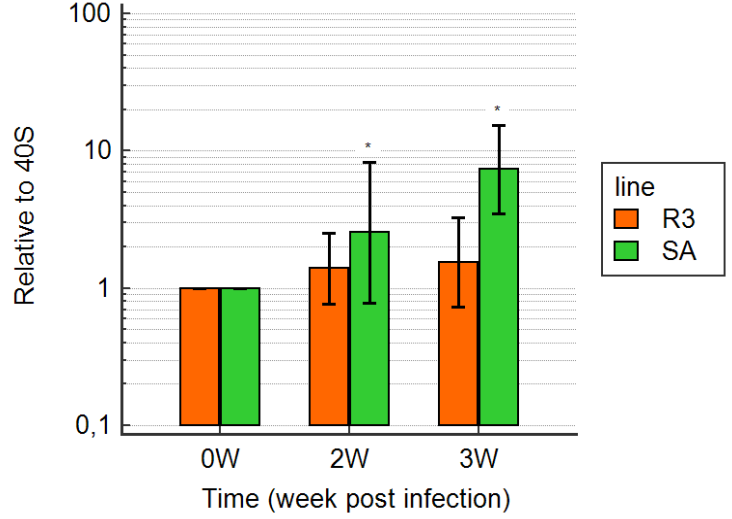

Fig. 4B. Transferrin receptor 1 b expression in strain R3 ( $\square$ ) and SA (घ) during Trypanoplasma borreli infection. Values after log transformation are expressed as a fold change $\pm \mathrm{SD}$ relative to $40 \mathrm{~S}$ $(n=5)$. Differences between the control group (not shown) and strains R3 and SA were considered significant for $\mathrm{P} \leq 0.05$ and marked with an asterisk. Differences between strains were considered significant for $\mathrm{P} \leq 0.05$ and marked with the asterisks

Similarly to the TfRla gene, the ferritin expression pattern (Fig. 4C) showed opposite trends in the two carp groups. SA carp showed a significant downregulation of ferritin at week 2 p.i. and then a restoration of its activity by week 3 p.i., whereas in R3 carp, an upregulation was noted in the same weeks p.i.

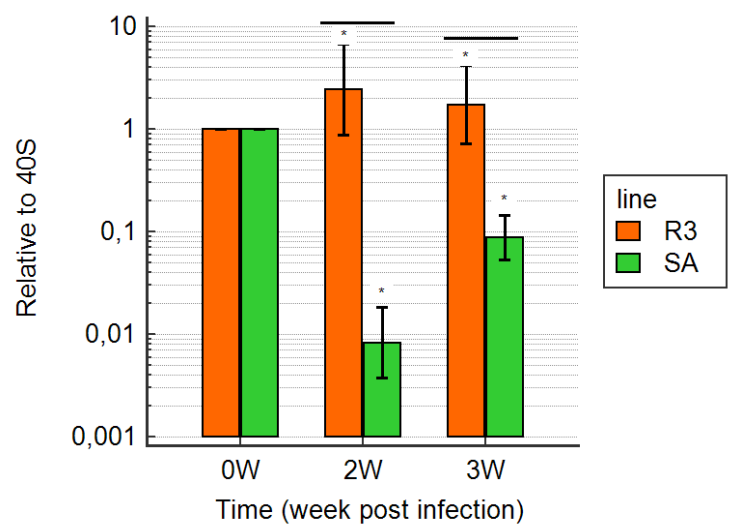

Fig. 4C. Ferritin expression in strain R3 ( $\square$ ) and SA ( $\square$ ) during Trypanoplasma borreli infection. Values after $\log$ transformation are expressed as a fold change SD relative to $40 \mathrm{~S}(\mathrm{n}=5)$. Differences between the control group (not shown) and strains R3 and SA were considered significant for $\mathrm{P} \leq 0.05$ and marked with an asterisk. Differences between strains were considered significant for $\mathrm{P} \leq 0.05$ in each time point and marked by a line

In contrast to ferritin and TfR1a genes, the transferrin expression pattern was comparable in both challenged groups. Parasitaemia caused down regulation of transferrin at week 2 p.i., but this drop was compensated for in week 3 p.i. in both challenged groups (Fig. 4D). 


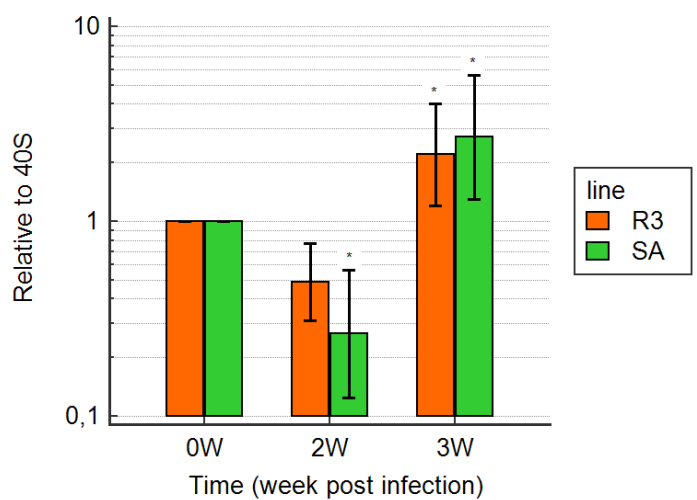

Fig. 4D. Transferrin expression in strain R3 ( $\square$ ) and SA ( $\bullet$ ) during Trypanoplasmaborreli infection. Values after $\log$ transformation are expressed as a fold change $\pm S D$ relative to $40 S(n=5)$. Differences between the control group (not shown) and strains R3 and SA were considered significant for $\mathrm{P} \leq 0.05$ and marked with an asterisk. Differences between strains were considered significant for $\mathrm{P} \leq 0.05$ and marked with the asterisks

\section{Discussion}

In the challenge with $T$. borreli, quite different responses in the two strains of carp were observed. The wild SA carp turned out to be more resistant than R3 strain, displaying a very low parasitaemia level and an almost $100 \%$ rate of survival. We can conclude that SA individuals are resistant to $T$. borreli, and that R3 carp are moderately susceptible.

Our study revealed that in healthy individuals of the SA strain, the average iron level was three times higher than in R3 carp. Considering that from the beginning of the experiment, both strains were bred in the same recirculating system with an identical feeding scheme, the observed difference is hard to attribute to external factors. It has been reported that in Polish commercial common carp, serum iron concentration is $27.1 \pm 5.6 \mathrm{mg} \mathrm{kg}^{-1}$ (4), which corresponds to the levels found in the R3 healthy individuals of our study. The lowest values were recorded at week 4 p.i. when the mortality reached the highest level which it maintained in the R3 strain. We found that a reduction in amount of iron is not related to individual parasite load. This suggests that the number of $T$. borreli in the bloodstream does not have to be very high in order to activate the mechanisms of Fe storage in ferritin.

It has been reported that parasites have the ability to bind to transferrin and internalise it, where it is then degraded in lysosomes (23). As a result, iron is obtained, and peptide fragments are released from trypanosomes. In both carp strains, we observed a similar pattern of transferrin expression, which indicates that $\mathrm{Tf}$ expression was regulated in the same manner in both strains, regardless of the pathogen load. Downregulation of transferrin expression in week 2 p.i. corresponded with the peak of parasitaemia. Probably, the host defence mechanism reduces the expression of transferrin and prevents iron acquisition from this protein. Interestingly, in week 3 p.i. we observed a significant upregulation of transferrin expression despite a decrease in serum iron concentration. Perhaps, transferrin mRNA is regulated at the protein level, or inflammation induces the formation of apo-Tf (iron-free transferrin). Ferritin also responds to parasite infection by increasing its expression in the R3 strain at weeks 2 and 3 p.i. This increase is consistent with serum iron decrease, making this element unavailable to the parasite. This is in accordance with previous findings for other species, where ferritin is upregulated upon inflammation: Neves et al. (19) reported overexpression of ferritin in sea bass liver during bacterial infection, whereas Feng et al. (7) showed ferritin upregulation in the spleen and head kidney in Atlantic cod after formalin-killed, atypical Aeromonas salmonicida stimulation. We also observed a correlation between ferritin and TfRla, suggesting that the expression of these genes is linked: an increased expression of TfR1a allows for the efficient mobilisation of iron to the cells and the storage of iron in ferritin. What is more, TfR $1 \mathrm{a}$ expression may increase upon overproduction of nitric oxide (NO), which is an inflammatory mediator. It has been reported that endogenously produced NO increases the activity of iron regulatory protein 1 (IRP1) which binds to iron responsive elements (IREs). IREs are located in the untranslated regions of the mRNA of transferrin receptor and ferritin, and the binding activity of IRP is regulated by the intracellular iron concentration (3). It has been reported that $T$. borreli activates NO production, which leads to extensive tissue nitration, but does not cause damage to the parasite $(8,28)$. Interestingly, TfR1b expression remained constant. This suggests that the regulation of TfR $1 \mathrm{~b}$ expression is not susceptible to parasite infection.

Ferritin expression in the SA strain was significantly downregulated in weeks 2 and 3 p.i., the opposite case to that of the R3 strain. Probably, the expression of ferritin in this carp strain was not associated with iron storage but with the generation of reactive oxygen species, which enhances the immune response.

Interestingly, analysis of the expression of TfR $1 \mathrm{a}$ in the SA strain showed that it was strongly downregulated in week 2 p.i. It has been found that the type I ('classical') response against a particular parasite activates the cytokines tumour necrosis factor- $\alpha$ (TNF- $\alpha$ ) and $\gamma$-interferon (IFN- $\gamma$ ) early during infection (27). It is also known that transferrin mRNA levels decrease following stimulation with IFN- $\gamma$ (26). This could mean that IFN- $\gamma$ not only reduces the expression of TfR1a, but also has no effect on TfR1b expression. Further investigation is required in order to properly analyse this phenomenon.

This report shows for the first time that an initial high level of iron in carp may prevent the growth of Trypanoplasma borreli. A similar conclusion has been made for mice infected with Leishmania major (25) which were overloaded with iron by injection. Further experiments in the field of iron levels and disease 
resistance in carp will be fundamental to understanding those mechanisms.

Conflict of Interests Statement: The authors declare that there is no conflict of interests regarding the publication of this article.

Financial Disclosure Statement: This work was supported by the National Science Centre, contract number UMO-2012/05/B/NZ6/01738.

Animal Rights Statement: The research was in compliance with Polish animal welfare regulations and approved by the II Local Ethics Committee for Animal Experimentation in Cracow, Poland.

Acknowledgments: We are grateful to Czesława GajChucher, Danuta Rajba-Nikiel, Jolanta Krzempek, Agnieszka Troszok, and Ludmiła Kolek for their assistance in sampling. We also express our admiration for the professional skills of Urszula Czudek and Michał Inglot who took care of the fish in the recirculating system and helped to perform challenges.

\section{References}

1. Aisen P., Enns C., Wessling-Resnick M.: Chemistry and biology of eukaryotic iron metabolism. Int J Biochem Cell Biol 2001, 33 , 940-959.

2. Bayne C.J., Gerwick L.: The acute phase response and innate immunity of fish. Develop Comp Immunol 2001, 25, 725-743.

3. Bogdan C.: Nitric oxide and the regulation of gene expression. Trends Cell Biol 2001, 11, 66-75.

4. Brucka-Jastrzębska E., Kawczuga D., Rajkowska M., Protasowicki M.: Levels of microelements $(\mathrm{Cu}, \mathrm{Zn}, \mathrm{Fe})$ and macroelements $(\mathrm{Mg}, \mathrm{Ca})$ in freshwater fish. J Elementol 2009, 14, 437-447.

5. Brzuska E.: Artificial propagation of female Hungarian strain 7 carp (Cyprinus carpio) after treatment with carp pituitary homogenate, Ovopel or Dagin. Czech J Anim Sci 2006, 51, 132-141.

6. Elvitigala D.A.S., Premachandra H.K.A., Whang I., Oh M.J., Jung S.J., Park C.J., Lee J.: A teleostean counterpart of ferritin M subunit from rock bream (Oplegnathusfasciatus): An active constituent in iron chelation and DNA protection against oxidative damage, with a modulated expression upon pathogen stress. Fish Shellfish Immunol 2013, 35, 1455-1465.

7. Feng C.Y., Johnson S.C., Hori T.S., Rise M., Hall J.R., Gamperl A.K., Hubert S., Kimball J., Bowman S., Rise M.L.: Identification and analysis of differential expressed genes in immune tissues of Atlantic cod stimulated with formalin-killed, atypical Aeromonassalmonicida. Physiol Genom 2009, 37, 149-163.

8. Forlenza M., Nakao M., Wibowo I., Joerink M., Arts J.A., Savelkoul H.F., Wiegertjes G.F.: Nitric oxide hinders antibody clearance from the surface of Trypanoplasma borreli and increases susceptibility to complement-mediated lysis. Mol Immunol 2009, 46, 3188-3197.

9. Gabay C., Kushner I.: Acute-phase protein and other systemic response to inflammation. New Engl J Med 1999, 340, 448-454.

10. Graham R.M., Chua A.C.G., Herbison C.E., Olynyk J.K., Trinder D.: Liver iron transport. World J Gastroenterol 2007, 13, 4725-4736.
11. Jurecka P., Irnazarow I., Westphal A.H., Forlenza M., Arts J.A.J., Savelhoul H.F.J., Wiegertjes G.F.: Allelic discrimination, three-dimensional analysis end gene expression of multiple transferrin alleles of common carp (Cyprinus carpio L.). Fish Shellfish Immunol 2009, 26, 573-581.

12. Kazuń K., Siwicki A.K.: Propiscine - a new safe anaesthetic for fish. Arch Polish Fisher 2001, 9, 95-102.

13. Liu H., Takano T., Abernathy J., Wang S., Sha Z., Jiang Y., Terhune J., Kucuktas H., Peatman E., Liu Z.: Structure and expression of transferrin gene of channel catfish, Ictalurus punctatus. Fish Shellfish Immunol 2010, 28, 159-166.

14. Liu Y., Yu S., Chai Y., Zhu Q.: Transferrin gene expression in response to LPS challenge and heavy metal exposure in roughskin sculpin (Trachidermus fasciatus). Fish Shellfish Immunol 2012, 32, 223-229.

15. Livak K.J., Schmittgen T.D.: Analysis of relative gene expression data using real-time quantitative PCR and the 2(-Delta Delta C(T)) Method. Methods 2001, 25, 402-408.

16. Lu X.J., Chen J., Huang Z.A., Zhuang L., Peng L.Z., Shi Y.H.: Influence of acute cadmium exposure on the liver proteome of a teleost fish, ayu (Plecoglossus altivelis). MolBiol Reports 2012, 39, 2851-2859.

17. Magarinos B., Romalde J.L., Lemos M.L., Barja J.L., Toranzo A.F.: Iron uptake by Pasteurella piscicida and its role in pathogenicity for fish. Appl Environ Microbiol 1994, 60, 2990-2998.

18. Mohd-Shaharuddin N., Mohd-Adnan A., Kua B.C., Nathan S.: Expression profile of immune-related genes in Lates calcarifer infected by Cryptocaryon irritans. Fish Shellfish Immunol 2013, $34,762-769$.

19. Neves J.V., Wilson J.M., Rodrigues P.N.S.: Transferrin and ferritin response to bacterial infection: The role of liver and brain in fish. Develop Comp Immunol 2009, 33, 848-857.

20. Peatman E., Baoprasertkul P., Terhune J., Xu P., Nandi S., Kucuktas H., Li P., Wang S., Somridhivej B., Dunham R., Liu Z. Expression analysis of the acute phase response in channel catfish (Ictalurus punctatus) after infection with a Gram-negative bacterium. Develop Comp Immunol 2007, 31, 1183-1196.

21. Schreiber G., Tsykin A., Aldred A.R., Thomas T., Fung W.P., Dickson P.W., Cole T., Birch H., de Jong F.A., Milland J.: The acute phase response in the rodent. Ann NY Acad Sci 1989, 557, 61-85.

22. Steinhagen D., Kruse P., Korting W.: Some haematological observations on carp, Cyprinus carpio L., experimentally infected with Trypanoplasma borreli Laveran \& Mesnil, 1901 (Protozoa: Kinetoplastida). J Fish Dis 1990, 13, 157-162.

23. Steverding D., Stierhof Y.D., Chaudhri M., Ligtenberg M., Schell D., Beck-Sickinger A.G., Overath P.: ESAG 6 and 7 products of Trypanosoma brucei form a transferrin binding protein complex. Europ J Cell Biol 1994, 64, 78-87.

24. Torti F.M., Torti S.V.: Regulation of ferritin genes and protein. Blood 2002, 99, 3505-3516

25. Vale-Costa S., Gomes-Pereira S., Miguel Teixeira C., Nuno Rodrigues P., Tomás A., Appelberg R., Salomé Gomes M.: Iron overload favors the elimination of Leishmania infantum from mouse tissues through interaction with reactive oxygen and nitrogen species. PLoS Neglected Trop Dis 2013, 7, e2061.

26. Weiss G., Bogdan C., Hentze M.W.: Pathways for regulation of macrophage iron metabolism by the anti-inflammatory cytokines IL-4 and Il-13. J Immunol 1997, 158, 420-425.

27. Wiegertjes G.F., Forlenza M., Joerink M., Scharsack J.P.: Parasite infection revisited. Develop Comp Immunol 2005, 29, 749-758.

28. Woo P.T.K., Ardeli B.F.: Immunity against selected piscine flagellates. Develop Comp Immunol 2014, 43, 268-279.

29. Yang C.G., Liu S.S., Sun B., Wang X.L., Wang N., Chen S.L.: Iron-metabolic function and potential antibacterial role of Hepcidin and its correlated genes (Ferroportin 1 and Transferrin Receptor) in turbot (Scophthalmus maximus). Fish Shellfish Immunol 2013, 34, 744-755. 